\title{
The Assessment of Biofuel Utilization Policy on the Total Output and $\mathrm{CO}_{2}$ Emissions in Thailand
}

\author{
Suthathip Suanmali ${ }^{1}$ and Bundit Limmeechokchai ${ }^{2}$ \\ ${ }^{1}$ Assistant Professor, School of Management Technology, Sirindhorn International Institute of Technology, Thammasat \\ University, Pathumthani, 12000, Thailand, Tel: +66-2-5013505 Ext 2114, Fax: +66-2-5013505 Ext 2101, \\ E-mail: ssuanma@gmail.com (Corresponding author). \\ ${ }^{2}$ Associate Professor, School of Manufacturing Systems and Mechanical Engineering, Sirindhorn International Institute \\ of Technology, Thammasat University, Pathumthani, 12000, Thailand, Tel: +66- 2-9869009 Ext 2206,
}

Fax: +66-2-5013505 Ext 2114, E-mail: bundit@siit.tu.ac.th.

Engineering Management

Received April 29, 2012; received revisions July 8, 2012; August 20, 2012; accepted August 27, 2012

Available online October 13, 2012

\begin{abstract}
The transport sector is the largest energy-consuming sector in Thailand. Its primary energy supply is heavily depended on imported oil. Since 2005, world crude oil price has been rising and had reached a record of $147 \$ /$ barrel. Therefore the policy on promotion of biofuel utilization was initiated in 2005 by the Ministry of Energy; however, the economy-wide impacts have been rarely assessed. This paper presents the energy Input-Output Analysis (IO) of the economy-wide impacts on the promotion policy, in particular, the change in Greenhouse Gas (GHG) emissions. In order to measure the total GHG emission from different economic sectors, the contribution of emissions has to be considered. In this paper, the focus is placed on $\mathrm{CO}_{2}$ emissions. To calculate the amount of $\mathrm{CO}_{2}$ emissions, the emission amount of various final consumptions in the economy evaluated by the $\mathrm{IO}$ must be applied. The direct $\mathrm{CO}_{2}$ emissions in final energy consumptions in Thailand are evaluated by using conversion factors from Guidelines to Defra's GHG conversion factors, Annexes updated in June 2007. The $\mathrm{CO}_{2}$ emissions in various economic sectors will be calculated and compared with the figures in 2015 when the policy is fully implemented.
\end{abstract}

Keywords: Biofuel utilization, GHG emissions, energy input-output analysis, energy assessment.

\section{Introduction}

The transport sector is the largest energy-consuming sector in Thailand, and the primary energy supply in this sector is heavily depended on imported oil. According to Alternative Energy Development Plan: AEDP 2012-2021, $80 \%$ of oil consumed in Thailand are imported from aboard. The rising of world crude oil price has greatly impact on the transport sector and Thai economy as a whole. Since 2005, the Ministry of Energy has set a target to promote the use of alternative energy in the transport sector to reduce the oil consumption and increase energy independency. The policy on promotion of biofuel was first initiated in 2005. As Thailand has been one of the fastest growing economies in South East Asia for the past twenty years and experienced a parallel increase in demand for energy to fuel its impressive industrial expansion, the Thai Government had set forth a sustainable energy plan that would address the country's short-term and long-term supply and demand issues, and which secures Thailand's future energy sufficiency.

Thai government has designated a 15 -year plan from 2008 to 2022 , and aimed at covering $20 \%$ of total national energy demand by reproducible energy. To begin with, the government has set a policy in 2008 to reduce oil consumption in the transport sector by $15 \%$ (Bhandhubanyong, 2006). Moreover, there is a two-phase strategy developed by Ministry of Energy (Gonsalves, 2006). The first phase concerns with replacement of MTBE (Methyl Tertiary Butyl Ether) and ETBE (Ethyl Tertiary Butyl Ether) in gasoline with ethanol. With this phase, the production of ethanol should be amplified to 1.155 million liter per day. In the second phase, gasohol mandate will stimulate ethanol production to satisfy the increasing gasohol users. In addition, the Energy Policy and Planning Office (EPPO) has launched a strategy aiming at reducing energy consumption in all sectors. Recently, from year 2008 to 2009, there was a 13\% increase in gasohol use (Energy Policy and Planning, 2009). In addition, the government has promoted the production and the use of biodiesel in order to reduce the country's imported fuel oil, reduce air pollution, and enhance the quality of life. It is estimated that the policy on promotion of biofuel will be fully implemented in 2015 . All diesel sold in Thailand will be $5 \%$ blended biodiesel, called B5, and gasoline will be blended with $20 \%$ ethanol, called E20. Consequently, the energy structure of Thailand; particularly in transport sectors, is changed due to the 
implementation of the promotion on biofuel utilization, and the study of its macroeconomics impacts has already been assessed by using the IO model (Suanmali et al, 2010). However, the economy-wide impacts on $\mathrm{CO}_{2}$ emission factors have been rarely assessed. In this paper, the focus is placed on $\mathrm{CO}_{2}$ emissions. To calculate the amount of $\mathrm{CO}_{2}$ emitted, the emission factors of various final consumptions in the economy, evaluated by the Input-Output Analysis (IOA), must be applied.

The Input-Output model was developed using the 2005 Input-Output table provided by the Office of the National Economic and Social Development Board (NESDB) (NESDB, 2009). For the analysis, all 180 sectors from the Input-Output table were carefully reorganized and reduced to 18 sectors (see Table 1). The direct $\mathrm{CO}_{2}$ emissions in the final energy consumption in Thailand are evaluated by using conversion factors from Guidelines to Defra's GHG conversion factors, Annexes updated in June 2007 as shown in Table 2. This paper is aimed at measuring $\mathrm{CO}_{2}$ emission factors in various economic sectors and comparison of factors in 2015 when the policy of promotion of biofuel utilization is fully implemented.

Table 1. Recognized sector

\begin{tabular}{cl}
\hline Sector & \\
\hline 1 & Agriculture \\
2 & Mining Cons \\
3 & Construction \\
4 & Commercial \\
5 & Road transportation \\
6 & Other transportation \\
7 & Food \& Beverages \\
8 & Textiles \\
9 & Wood and Furniture \\
10 & Paper \\
11 & Chemical \\
12 & Non-Metallic \\
13 & Basic Metallic \\
14 & Fabricated Metal \\
15 & Coal and its products \\
16 & Petroleum products and natural gases \\
17 & Electricity \\
18 & Others \\
\hline
\end{tabular}

Table 2. Conversion factor

\begin{tabular}{cccccc}
\hline \multicolumn{5}{c}{ Standard Road Transport Fuel Conversion Factor } \\
\hline $\begin{array}{c}\text { Fuel } \\
\text { used }\end{array}$ & $\begin{array}{c}\text { Total units } \\
\text { used }\end{array}$ & \multirow{2}{*}{ Units } & x & $\begin{array}{c}\mathrm{kg} \mathrm{CO}_{2} \\
\text { per unit }\end{array}$ & $\begin{array}{c}\text { Total kg } \\
\mathrm{CO}_{2}\end{array}$ \\
\hline Petrol & units used & liters & x & 2.3154 & $\mathrm{~kg} \mathrm{of} \mathrm{CO}_{2}$ \\
Diesel & units used & liters & $\mathrm{x}$ & 2.6304 & $\mathrm{~kg} \mathrm{of} \mathrm{CO}_{2}$ \\
\hline
\end{tabular}

\section{Policies and Situation in Thailand}

Thailand has a population of 63 million; it draws $49 \%$ of national annual consumption of energy from overseas countries. It imports $85 \%$ of crude oil annually. To decrease import dependency of energy, Thai government has designated a 15-years plan from fiscal year 2008 to fiscal year 2022 to cover $20 \%$ of total national energy demand by renewable energy.
The Government has also formulated a strategy to ensure that by 2012 all the diesel sold in Thailand will be $10 \%$ biodiesel (B10). In addition, Thailand's Energy Policy was delivered to the cabinet on December 30, 2008 by Mr. Abhisit Vejjajiva, former Prime Minister of Thailand to emphasis the promotion the production and utilization of biofuels. It has become a national agenda by encouraging the production and the use of alternative energy, particularly biodiesel (B5, B10).

Biodiesel is the name given to these esters when they are intended for use as transportation fuel. Biodiesel is blended with petroleum diesel. There are three main type of biodiesel: B2, B5 and B10. The number listed after a letter ' $\mathrm{B}$ ' indicates the percentage of biodiesel blended in the combination with petrol. B2 was introduced in the market in 2008. Afterwards, B5 was first sold in the market in 2007 and extended nationwide in 2011. Also, B10 was set to be used with any diesel engines in 2012 .

Global warming is currently an important agenda worldwide. A higher in the average temperature leads to many problems including a rise in sea level and an increase in the frequency of some extreme weather events. A long-term renewable energy policy on lower $\mathrm{CO}_{2}$ emission should be considered. The policy on promotion of biofuel utilization in transport sector is a way that will certainly reduce the amount of $\mathrm{CO}_{2}$ emissions. The plan is clearly presented to the Parliament that Thailand will be aiming at Green house emission reduction (NuntJaruwong, 2011). In 2012 -2016, the focus will be placed on development of alternative energy technology industry, encourage new alternative energy $R \& D$ to achieve economic viability including new technologies for biofuels production and introduce a model development of Green City to communities for sufficient economy and sustainability development. The long term from 2017 to 2022, Thailand will enhance utilization of new available alternative energy technologies such as hydrogen, bio hydrogenated (BHD), extend green city models throughout Thai communities and encourage to be hub of biofuel and alternative energy technology exports in ASEAN regions. These midterm and long term plans require the cooperation from experts in inter-disciplinary areas such as engineering, environmental, economic business, and agricultural researchers. Engineering and production management is an important key in this situation as it will gathers researchers and industry experts to come up with an efficient solution or plan to increase the proportion of renewable energy production and utilization in Thailand (Ko, 2011).

\section{Research Methodology}

In this paper the IO model (Wassily, 1986) is applied. When the government initiates the policies, they will have both direct and indirect effects on many industries of the entire economy because the total consumption of a particular product at the final and intermediate levels will represent final demand in the economy. This is applicable to the final energy demand.

One important step in developing the model is to determine the total requirement from the economy. It can be obtained from the sum of the final consumption and the intermediate requirements for intermediate sectors (Miller and Blair, 1985). Thus, if the economic structure consists of $\mathrm{n}$ sectors, we define the following variables as 
$X_{i}=$ The total output or production of sector $i$.

$Y_{i}=$ The total final demand for sector i's product.

$Z_{i j}=$ The inter-industry sales by sector $i$ to sector $j$,

Where

$1 \leq i, j \leq n$. The equation that describes the relationship among $X_{i}, Y_{i}$ and $z_{i j}$ in each sector $i$ can be expressed in Eq. (1) as

$$
X_{i}=z_{i 1}+z_{i 2}+\cdots+z_{i n}+Y_{i} .
$$

The technical coefficient or input coefficient is the ratio between input and output of each sector and is denoted as $a_{i j}$, where

$$
a_{i j}=\frac{Z_{i j}}{X_{j}} .
$$

Then, we define

$$
X_{j}=\min \left(\frac{z_{1 j}}{a_{1 j}}=\frac{z_{2 j}}{a_{2 j}}=\cdots=\frac{z_{n j}}{a_{n j}}\right)
$$

Hence, the relationship among $X_{i}, Y_{i}$ and $z_{i j}$ in all n sectors can be described as

$$
\begin{aligned}
& X_{1}=a_{11} X_{1}+a_{12} X_{2}+\cdots+a_{1 i} X_{i}+\cdots+a_{1 n} X_{n}+Y_{1} \\
& \vdots \\
& X_{i}=a_{i 1} X_{1}+a_{i 2} X_{2}+\cdots+a_{i i} X_{i}+\cdots+a_{i n} X_{n}+Y_{i} \\
& \vdots \\
& X_{n}=a_{n 1} X_{1}+a_{n 2} X_{2}+\cdots+a_{n i} X_{i}+\cdots+a_{n n} X_{n}+Y_{n} .
\end{aligned}
$$

Then, we rearrange Eq. (4) and each place the variable $Y_{i}$ on the right-hand side; the equation becomes

$$
(I-A) X=Y \text {, }
$$

\section{Where}

$I$ is an identity matrix of order $\mathrm{n}, A=\left(a_{i j}\right)$ is an $n \times n$ matrix, and both $\mathrm{X}$ and $\mathrm{Y}$ are $n \times 1$ vectors. Thereby,

$$
X=(I-A)^{-1} Y,
$$

and the matrix $(I-A)^{-1}$ is referred as Leontief inverse.

When the energy substitution policy is implemented, the final demand will change. Subsequently, the change in final demand will alter the total output of production, which is the focus of this paper. Therefore, the Eq. (6) is developed into $\Delta X=(I-A)^{-1} \Delta Y$
In addition, certain assumptions are required. First, there is no great variation in economic change from the year 2005 till present. That is, the economic structure and the flows between sectors remain just about the same. Second, most biofuel are used in road transportation (sector 5). Trucks, trailers, railways and water transports use diesel as the main fuel. Third, biofuel is produced from agricultural crops; consequently, an increase in biofuel demand would increase the final energy demand in sector 1. Fourth, the demands of other unrelated/irrelevant sectors remained unchanged. Hence, the impact of this energy substitution policy will be placed only upon agriculture and transportation sectors. Hence, the change in final energy demand in these sectors is nonzero, and all other entries equal zero. Fifth, the engine or technology efficiency is constant.

The final energy demand vector, $Y_{i}$, is derived from the 2007 Energy Report in the same way as the study done on ethanol utilization (Suanmali et al., 2010). The business as usual (BAU) case or base case of fuel consumption in Thailand's transport sector is calculated. It is obtained that in the BAU case the final energy demand in agricultural and transportation sectors are 31,374,306 thousand Baht and 571,740,092 thousand Baht respectively. In order to evaluate the impacts of the biodiesel utilization policy on the change in the total output of the agricultural and transport sectors, three structural changes are considered in this paper. They are $100 \%$ utilization of B5, 100\% utilization of $\mathrm{B} 10$, and $50 \%$ utilization of both $\mathrm{B} 5$ and $\mathrm{B} 10$.

In addition to assessment of the economy-wide impacts of biodiesel utilization policy, the total $\mathrm{CO}_{2}$ emitted in each sector can be obtained through the Leontief inverse or $(I-A)^{-1}$ (Limmeechokchai and Suksuntornsiri, 2007). A matrix of energy consumption of each in the 18 sectors is defined and is denoted as a matrix $F$. Its dimension is $k \times n$, where $\mathrm{n}$ is the number of sectors and $k$ is the number of fuel types. Thus, each entry of matrix $F, F_{k i}$, is the direct consumption of fuel $k$ in a physical unit by the monetary output of economic sector $I$ (Limmeechokchai and Suksuntornsiri, 2007). The focus of this study was placed on two types of fuel - gasoline and diesel. Therefore, $F$ is a $2 \times 18$ matrix in this study as shown in Table 3 . Then, each element, $F_{k i}$, where $1 \leq i \leq 18$ and $1 \leq k \leq 2$, is multiplied by its corresponding conversion factor demonstrated in Table 2 as shown in Eq. (7)

$$
B_{k i}=F_{k i} \times \text { conversion factor } r_{k i}
$$

The matrix $B=\left(B_{k i}\right)$ is a matrix of sectoral $\mathrm{CO}_{2}$ emission. The study of Limmeechokchai and Suksuntornsiri (2007) supported that the emission of $\mathrm{CO}_{2}$ relies on the fuel type $k$, and the total $\mathrm{CO}_{2}$ emission or $\mathrm{bCO}_{2}$ is obtained through a calculation in Eq. (8)

$$
b \mathrm{CO}_{2}=B(I-A)^{-1}
$$

Because the implementation of the promotion of biofuel utilization is mainly focused on the transport sector, the measure of $\mathrm{CO}_{2}$ emissions in this study is emphasized on agricultural and transport sectors. In addition, year 2005 is defined as the base year in order to compare $\mathrm{CO}_{2}$ 
emissions with those in 2015 when the policy of promotion of biofuel utilization is fully implemented.

A simple linear regression is employed to predict the sectoral energy consumption matrix of each fuel type (gasoline and diesel) in year 2015 denoted as $F^{2015}$. The elements of matrix $F^{2015}$ are the predicted gasoline and diesel consumptions in each sector assuming that the policy is not implemented. Then from matrix $F^{2015}$, the sectoral energy consumption matrix of each fuel type (gasoline and diesel) in 2015 is predicted under the assumption that the biofuel utilization policy is fully implemented. It is observed that the implementation of utilizing E20 instead of gasoline and B5 instead of diesel is applied to the transport sector only (sectors 5 and 6). Hence, the elements of matrix $F^{2015}$ in sectors 5 and 6 are adjusted by multiplying them by a gasoline mixture ratio 0.80 for E20 and 0.95 for B5. The deleted 20\% of gasoline and $5 \%$ of diesel are, thereby, added to agricultural sector as ethanol and biodiesel are by-products of that sector. The overview of each entry in the adjusted $F^{2015}$ matrix is described in Table 4.

Table 3. Matrix F of Energy Consumption in each sector

\begin{tabular}{ccccc}
\hline & Sector 1 & Sector 2 & $\ldots$ & $\begin{array}{c}\text { Sector } \\
18\end{array}$ \\
\hline $\begin{array}{c}\text { Gasoline } \\
\text { (Liters) }\end{array}$ & $F_{11}$ & $F_{12}$ & $F_{1 i}$ & $F_{1,18}$ \\
Diesel (Liters) & $F_{21}$ & $F_{22}$ & $F_{2 i}$ & $F_{2,18}$ \\
\hline
\end{tabular}

\section{Results}

\subsection{Part I: Assessment of Biodiesel Utilization Policy}

After the change in final energy demand vector or $\Delta Y$ in each of the three structural changes is obtained, the change in total output of production vector or $\Delta X$ is found. The results from the IO model for case 1 , case 2 and case 3 are summarized in tables 5 - 7 respectively, where case 1 is for $100 \%$ utilization of B5 in the transport sector. Case 2 and case 3 are for $100 \%$ utilization of B10, and $50 \%$ utilization of both B5 and B10 in the transport sector respectively.

When $100 \%$ of B5 is utilized, the final energy demand in the agricultural sector rises by 26,067 million Baht $(\Delta \mathrm{Y})$ or increases by $52.21 \%$. So the output of production in this sector increases by 26,224 million Baht $(\Delta X)$. On the other hand, the final energy demands in the transport sector decreases by 48,244 million Baht or decreases by $17.02 \%$ with the total output production decreases by 48,246 million Baht or decreases by $17.02 \%$.

In the situation where $100 \%$ of $\mathrm{B} 10$ is utilized, it requires more biodiesel in the energy mix. It is estimated that doubling biodiesel is required. As a result, this policy helps to promote agricultural sector by $112.72 \%$ or, numerically, 57,788 million Baht. This is because more crops; especially palm oil, jatropha oil, soy bean oil, physic nut (black soap) and vegetable oils, are required for biodiesel production. If $100 \%$ of B10 is implemented, the final energy demand in the transport sector decreases by $5.53 \%$ and the total output of production decreases by $19.52 \%$.

If $50 \%$ of $\mathrm{B} 5$ and $\mathrm{B} 10$ is implemented, the final energy demand in the agricultural sector increases by 41,754 million Baht or increases by $83.63 \%$, while the total output of production in this sector increases by 42,006 million Baht or $81.94 \%$. On the other hand, the result show that this policy will reduce the final energy demand and the total output production in the transport sector; the final energy demand decreases by $18.30 \%$ and the total output of production decreases by $18.29 \%$.

\subsection{Part II: Assessment of $\mathrm{CO}_{2}$ Emissions}

The $\mathrm{CO}_{2}$ emissions from final consumptions in the base year 2005 are presented in Table $8 . \mathrm{CO}_{2}$ emissions in each sector in 2015 are also summarized in Table 8 . The fourth column presents $\mathrm{CO}_{2}$ emissions in 2015 when the biofuel utilization policy is fully implemented. The results in each sector are obtained from the adjusted matrix $F^{2015}$ as explained in Table 4. The focus is kept on for the agricultural and transport sectors. The percentage changes of $\mathrm{CO}_{2}$ emissions in 2015 when the policy is implemented in these mentioned sectors are demonstrated in Table 9.

The amount of $\mathrm{CO}_{2}$ emissions in each economic sector depends on the amount of fuel and fuel types (gasoline and diesel). In 2005, road transportation (sector 5) has the highest $\mathrm{CO}_{2}$ emissions, followed by agricultural sector (sector 1) and other transportation sector (sectors 6 trucks, trailers, railways, air, and water transportations). Similar results are obtained in 2015 as $\mathrm{CO}_{2}$ is emitted mostly in the sector 5 .

Table 4. The Adjusted F2015 Matrix that Reflect the Implementation of the Biofuel Utilization Policy in Transport Sector

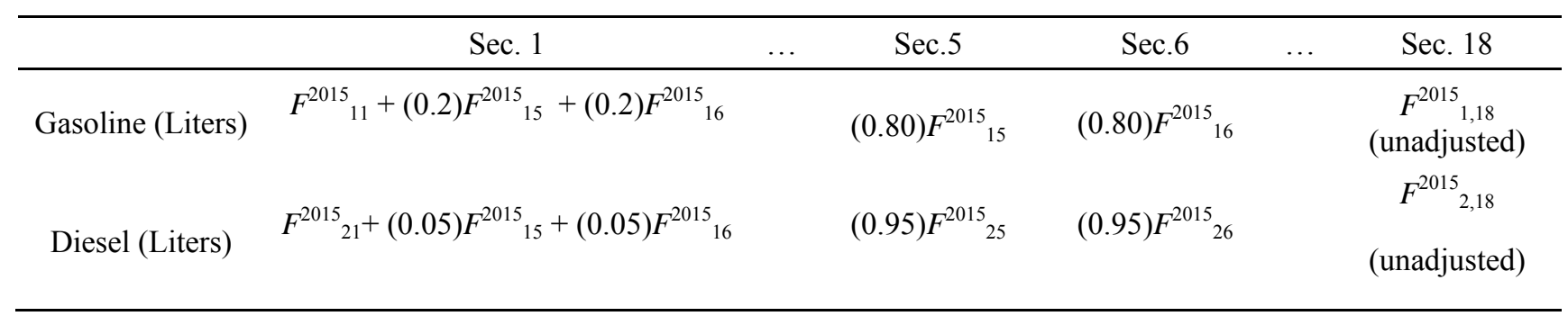


Table 5. Summary of $\Delta Y$ and $\Delta X$ when $100 \%$ of B5 is Utilized.

\begin{tabular}{|c|c|c|c|c|c|c|c|}
\hline & B5 & $\begin{array}{c}\text { Final } \\
\text { Energy } \\
\text { Demand } \\
(\mathrm{Y}) \\
(1010 \\
\text { Baht })\end{array}$ & $\begin{array}{l}\text { Change in } \\
\text { Final } \\
\text { Energy } \\
\text { Demand } \\
(\Delta \mathrm{Y})(1010 \\
\text { Baht })\end{array}$ & $\begin{array}{c}\text { Percentage } \\
\text { Change }\end{array}$ & $\begin{array}{c}\text { Total } \\
\text { Output of } \\
\text { Production } \\
(\mathrm{X})(1010 \\
\text { Baht })\end{array}$ & $\begin{array}{c}\text { Change in } \\
\text { Total Output } \\
\text { of } \\
\text { Production } \\
\text { (delta X) } \\
\text { (1010 Baht) }\end{array}$ & $\begin{array}{c}\text { Percentage } \\
\text { Change }\end{array}$ \\
\hline & Business as usual & 4.9925 & & & 5.1265 & & \\
\hline $\begin{array}{l}\text { Agricultural } \\
\text { Sector }\end{array}$ & Policy implemented & 7.5992 & 2.6067 & $52.21 \%$ & 7.7489 & 2.6224 & $51.15 \%$ \\
\hline Transport & Business as usual & 28.3471 & & & 28.3501 & & \\
\hline Sector & Policy implemented & 23.5227 & -4.8244 & $-17.02 \%$ & 23.5255 & -4.8246 & $-17.02 \%$ \\
\hline
\end{tabular}

Table 6. Summary of $\Delta Y$ and $\Delta X$ when $100 \%$ of B10 is Utilized.

\begin{tabular}{|c|c|c|c|c|c|c|c|}
\hline & B10 & $\begin{array}{c}\text { Final } \\
\text { Energy } \\
\text { Demand } \\
(\mathrm{Y}) \\
(1010 \\
\text { Baht })\end{array}$ & $\begin{array}{c}\text { Change in } \\
\text { Final } \\
\text { Energy } \\
\text { Demand } \\
(\Delta \mathrm{Y})(1010 \\
\text { Baht })\end{array}$ & $\begin{array}{l}\text { Percentage } \\
\text { Change }\end{array}$ & $\begin{array}{c}\text { Total } \\
\text { Output of } \\
\text { Production } \\
(\mathrm{X})(1010 \\
\text { Baht })\end{array}$ & $\begin{array}{l}\text { Change in } \\
\text { Total Output } \\
\text { of } \\
\text { Production } \\
\text { (delta X) } \\
\text { (1010 Baht) }\end{array}$ & $\begin{array}{c}\text { Percentage } \\
\text { Change }\end{array}$ \\
\hline \multirow[b]{2}{*}{$\begin{array}{l}\text { Agricultural } \\
\text { Sector }\end{array}$} & Business as usual & 4.9925 & & & 5.1265 & & \\
\hline & Policy implemented & 10.7366 & 5.7441 & $115.05 \%$ & 10.9053 & 5.7788 & $112.72 \%$ \\
\hline \multirow{2}{*}{$\begin{array}{l}\text { Road } \\
\text { transport } \\
\text { Sector }\end{array}$} & Business as usual & 28.3471 & & & 28.3501 & & \\
\hline & Policy implemented & 22.8144 & -5.5327 & $-19.52 \%$ & 22.8172 & -5.5329 & $-19.52 \%$ \\
\hline
\end{tabular}

Table 7. Summary of $\Delta Y$ and $\Delta X$ when $50 \%$ of $\mathrm{B} 5$ and $50 \%$ of $\mathrm{B} 10$ are Utilized.

\begin{tabular}{cccccccc}
\hline & & $\begin{array}{c}\text { Final } \\
\text { Energy } \\
\text { Demand } \\
(\mathrm{Y}) \\
(1010 \\
\text { Baht })\end{array}$ & $\begin{array}{c}\text { Change in } \\
\text { Final } \\
\text { Energy } \\
\text { Demand } \\
(\Delta \mathrm{Y})(1010 \\
\text { Baht })\end{array}$ & $\begin{array}{c}\text { Percentage } \\
\text { Change }\end{array}$ & $\begin{array}{c}\text { Total } \\
\text { Output of } \\
\text { Production } \\
(\mathrm{X})(1010 \\
\text { Baht })\end{array}$ & $\begin{array}{c}\text { Change in } \\
\text { Total Output } \\
\text { of } \\
\text { Production } \\
\text { (delta X) } \\
(1010 \text { Baht) }\end{array}$ & $\begin{array}{c}\text { Percentage } \\
\text { Change }\end{array}$ \\
\hline $\begin{array}{c}\text { Agricultural } \\
\text { Sector }\end{array}$ & Business as usual & 4.9925 & & & 5.1265 & & \\
$\begin{array}{c}\text { Road } \\
\text { transport } \\
\text { Sector }\end{array}$ & Policy implemented & 9.1679 & 4.1754 & $83.63 \%$ & 9.3271 & 4.2006 & $81.94 \%$ \\
\hline
\end{tabular}




\section{Conclusion}

From the analysis, The Input-Output model indicates the macroeconomic impacts. The results from tables 5-7 indicate that once there is a change in the energy sectors, the impact will be on several industrial sectors; in particular, in the agricultural sector and transport sectors.

The results of $100 \%$ utilization of B5 pointed out that for a one Baht increased in final energy demand then, the agricultural sector will increase the total output in the same sector by 1.00602 Baht. In addition, if the $100 \%$ utilization of B10 is implemented, a one Baht increased in final energy demand in the agricultural sector will increase the total output by $1.00605 \mathrm{Baht}$, which is higher than the case of B5. Lastly, for the $50 \%$ of B5 and $50 \%$ of B10 is implemented, a one baht increase in final energy demand in agricultural sector will increase the total output of production by 1.00604 Baht. Proportionally, a decline of one Baht in final energy demand of the transport sector will decrease the total output by 1.00004 Baht if $100 \%$ of B5 is implemented. On the other hand, if $100 \%$ of B10 is implemented, the proportion of a decrease in final energy demand to the total output in the transport sector is $1: 1.00009$. Also, if the third case is implemented, the ratio will be 1: 1.00003. For comparative efficiency, the increase of output in the agricultural sector must be compared with the decrease of output in the road transport sector. The utilization of $100 \%$ utilization of B10 is the most promising policy that should be implemented because it gives the highest value of output in the agricultural sector.

In addition to the assessment of biodiesel utilization policy, the assessment of $\mathrm{CO}_{2}$ emissions reveals that requirement of fossil-fuel directly affects the amount of $\mathrm{CO}_{2}$ emissions. The transport sector (both sectors 5 and 6 ) are the highest fossil-fuel consuming sector and have the high $\mathrm{CO}_{2}$ emissions. The trend of $\mathrm{CO}_{2}$ emissions would be lower in the case of a successful utilization of renewable energy; particularly, the transport sector could be lower by almost $10 \%$.

Finally, Thailand will be able to produce biofuel domestically, so promoting the utilization of this alternative energy will also increase the output in agricultural sector due to the higher demand in biofuel production. Most of all, the implementation of the biofuel utilization would certainly reduce the amount of imported fuels, increase Thailand's energy independency, and decrease $\mathrm{CO}_{2}$ emissions

\section{Acknowledgement}

This research is supported under the research grant of Thailand Research Fund and the Office of Higher Education Commission: MRG 5280083. The authors would like to acknowledge the funding. In addition, the authors would like to acknowledge Vorasett Wattanapradit, Sangket Chotiwongchai, Samata Krittayadaycho, Natacha Retthip, Jutaphon Noisak, and Mukda Phomtarawong for assistance in preparing and collecting data for this research.

Table 8. Summary of $\mathrm{CO}_{2}$ Emissions in the Sectors

\begin{tabular}{cccc}
\hline \multirow{2}{*}{ Sectors } & $\begin{array}{c}\mathrm{CO}_{2} \text { Emissions in 2005 } \\
\text { (ton } \mathrm{CO}_{2} \text { (million Baht) }\end{array}$ & \multicolumn{2}{c}{$\begin{array}{c}\mathrm{CO}_{2} \text { Emissions in 2015 } \\
\text { (ton } \mathrm{CO}_{2} / \text { million Baht) }\end{array}$} \\
\cline { 2 - 4 } 1 & Based Year & No Policy is Implemented & Policy of Utilizing Biofuel is Implemented \\
\hline 2 & 10.35 & 10.53 & 14.95 \\
3 & 0.06 & 0.06 & 0.05 \\
4 & 0.35 & 0.35 & 0.35 \\
5 & 0.03 & 0.03 & 0.04 \\
6 & 47.47 & 5.67 & 44.52 \\
7 & 4.99 & 0.84 & 5.39 \\
8 & 0.84 & 0.04 & 0.88 \\
9 & 0.04 & 0.09 & 0.05 \\
10 & 0.09 & 0.08 & 0.09 \\
11 & 0.08 & 0.60 & 0.08 \\
12 & 0.60 & 0.22 & 0.61 \\
13 & 0.22 & 0.09 & 0.22 \\
14 & 0.09 & 0.13 & 0.09 \\
15 & 0.13 & 0.00 & 0.13 \\
16 & 0.00 & 0.00 & 0.00 \\
17 & 0.00 & 0.22 & 0.00 \\
18 & 0.22 & 0.72 & 0.22 \\
& 0.72 & & 0.72 \\
\hline
\end{tabular}


Table 9. Percentage of Changes in $\mathrm{CO}_{2}$ Emissions when the Policy is Implemented

\begin{tabular}{cccc}
\hline \multirow{2}{*}{ Sector } & \multicolumn{2}{c}{$\mathrm{CO}_{2}$ Emissions in 2015 (ton $\mathrm{CO}_{2} /$ million Baht) } & \multirow{2}{*}{$\%$ Changes } \\
\cline { 2 - 3 } & No Policy is Implemented & Policy of Utilizing Biofuel is Implemented & $+41.970 \%$ \\
2 & 10.53 & 14.95 & $-5.000 \%$ \\
3 & 0.06 & 0.05 & $-0.090 \%$ \\
4 & 0.35 & 0.35 & $+30.050 \%$ \\
5 & 0.03 & 0.04 & $-9.470 \%$ \\
6 & 49.18 & 44.52 & $-4.500 \%$ \\
7 & 5.67 & 5.39 & $+3.820 \%$ \\
8 & 0.84 & 0.88 & $+6.460 \%$ \\
9 & 0.04 & 0.05 & $+2.650 \%$ \\
10 & 0.09 & 0.09 & $+0.350 \%$ \\
11 & 0.08 & 0.08 & $+1.590 \%$ \\
12 & 0.60 & 0.61 & $-0.010 \%$ \\
13 & 0.22 & 0.22 & $-0.040 \%$ \\
14 & 0.09 & 0.09 & $-0.060 \%$ \\
15 & 0.13 & 0.13 & $+40.030 \%$ \\
16 & 0.00 & 0.00 & $+10.440 \%$ \\
17 & 0.00 & 0.00 & $-0.006 \%$ \\
18 & 0.22 & 0.22 & $+0.162 \%$ \\
\hline
\end{tabular}

\section{References}

Bhandhubanyong, P. (2006). Development of Ethanol as a Transportation Fuel in Thailand, MTEC and NSTDA, Bangkok.

Department of Alternative Energy Development and Efficiency. (2008). 2550 / Oil and Thailand 2007 Report, Ministry of Energy, Bangkok.

Energy Policy and Planning. (2009). Office, Four Strategies to Increase Potentials to Handle Global Energy Crisis, Ministry of Energy, Bangkok.

Gonsalves, J. B. (2006). An Assessment of the Biofuels Industry in Thailand, United Nations Conference on Trade and Development.

Ko, C. H. (2011). Integration of Engineering, Project, and Production Management, Journal of Engineering, Project, and Production Management, 1(1), 1-2.

Limmeechokchai, B. and Suksuntornsiri, P. (2007). Embedded Energy and Total Greebnhouse Gas Emissions in Final Consumptions within Thailand. Renewable and Sustainable Energy Reviews, 11, 259-281.

Meyer, C. D. (2000). "Matrix Analysis and Applied Linear Algebra" SIAM, Philadelphia.

Miller, R. E. and Blair, P. D. (1985). Input-output Analysis: Foundation and Extension, New Jersey: Prentice-Hall.

Ministry of Energy. (2012). Alternative Energy Development Plan: AEDP, 2012-2021.

National Economic and Social Development Board (NESDB). (2009). 2005 Energy Input-Output Tables. Available from: http://www.nesdb.go.th (Accessed September 2009).
Nunt-Jaruwong, S. (2011). Thailand's New and Renewable Energy Programs and Policies, APEC New and Renewable Energy Technologies Expert Group.

Suanmali, S., Limmeechokchai, B., Phumitanon, C., Jaijitman, R., and Tansirichaiya, S. (2010). The Macroeconomics Impacts on Ethanol Utilization Policy in Thailand's Transport Sector Using InputOutput Analysis, Journal of International Management Studies, 10, 180-185.

Wassily, L. (1986). Input-Output Economics, $2^{\text {nd }}$ Edition, Oxford University Press, USA.

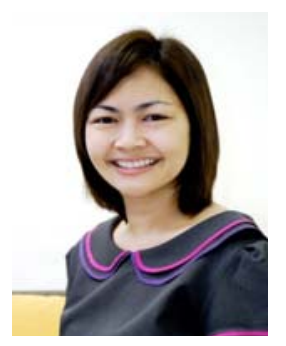

Suthathip Suanmali, Ph.D. received her Ph.D. in Mathematics from North Carolina State University in 2007. Currently, she is an assistant head to Transportation Research Center (TREC) and an Assistant Professor of School of Management Technology at Sirindhorn International Institute of Technology (SIIT), Thammasat University. Her research interests lie in the area of applied linear algebra, input-output model and highways maintenance system. 
64 S. Suanmali and B. Limmeechokchai

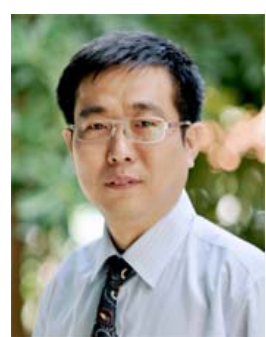

Bundit Limmeechokchai, Ph.D. received his Ph.D. in Energy Economics and Planning from Asian Institute of Technology, Thailand. Currently, he is an associated Professor of School Manufacturing Systems and Mechanical Engineering (MSME) of Technology (SIIT), Thammasat University. His research interests include Energy technologies, Energy efficiency, Energy economics, planning and policy, Modeling of energy and environment systems, Renewable energy, Low-carbon technologies, Demand-side management, Integrated resource planning, $\mathrm{CO} 2$ mitigation. 